\title{
Comparison the analgesic activity of watery suspension of Nigella sativa Linn. seeds with Naproxen in mice
}

\author{
W. H. Al-Shebani \\ F. J. Al-Tahan \\ Vet. Med. Coll./ Univ of Al-Qadisiya Vet. Med. Coll./ Univ of Baghdad
}

\begin{abstract}
The present study was designed to investigated the antinociceptive effect of the watery suspension of Nigella sativa seeds compared with that of Naproxen by using hot plate test, which mainly measures the threshold of stimulus required to elicit a response, in mice at 30,60, 90, 120 minutes after administration of the test agents. Twenty four albino Swiss mice of either sex were divided in four groups with (6) animals each, the first group was treated orally with $1000 \mathrm{mg} / \mathrm{kg}$ BW of watery suspension of Nigella seeds, the second group was treated orally with naproxen at dose of $500 \mathrm{mg} / \mathrm{kg} \mathrm{BW}$, the third group drenched with $500 \mathrm{mg} / \mathrm{kg} \mathrm{BW}$ of watery suspension of Nigella seeds and $250 \mathrm{mg} / \mathrm{kg} \mathrm{BW}$ of naproxen, whereas the last group serve as control. Nigella sativa seeds suspension significantly $(\mathrm{p}<0.05)$ prolonged the latency of response at all posttreatment observation times $(30,60,90$ and 120 minutes), the analgesic action of naproxen was diminished with time compared with Nigella seeds.Combination of equal amounts of Nigella seeds and Naproxen (half the originally used doses) caused significant increment $(\mathrm{p}<0.05)$ of analgesic reaction time longer than shown by each agent when given alone indicating an obvious synergistic effect between watery suspension of Nigella seeds and Naproxen.
\end{abstract}

\section{Introduction}

Since prehistoric times, humans have attempted to alleviate aliments or injuries with the aid of plant parts or herbal preparations. Ancient civilizations have recorded various prescriptions of this kind. In the herbal formularies of medieval times numerous plants were promoted as remedies. In modern medicine, where each drug is required to satisfy objective criteria of efficacy, hundreds of reputedly curative plants species have survived as drugs with documented effectiveness(1). One of these herbs was Nigella sativa which has substantial historical tradition in medicine.In spite of large number of pharmacological studies carried out world wide on Nigella sativa seed, recent references like (3) explained that Nigella sativa is truly an amazing combination, but there are still many components that haven't been yet identified, but research is going on around world.Pain is unpleasant sensory and emotional experience associated with actual or potential tissue damage ,or described in terms of such damage. It is a common symptom and important because it both signals "disease"(in the broadest sense) and aids diagnosis.However, by definition, it is a wretched sensation, and its relief is one of the most duties of a doctors(4) .Nigella sativa oil was used traditionally as a topical treatment for pain and stiffness in joint (5).It is well known that traditionally and publically plants in general and Nigella seeds in particular are taken or prescribed for patients in the form of a kind of tea i.e. the powder of the seeds is macerated or simply boiled to prepare a remedy. It has then been resumed that a need to perform an investigation as an aim of the present study focusing on the analgesic activity of watery suspension of Nigella sativa seeds, and extending to compare with other drug "naproxen" in mice by using hot plate test at different post-treatment time intervals . 


\section{Materials and methods}

Animals:

Twenty albino swiss mice of either sex weighing 24-32 g with an average (28 \pm 2$)$ were obtained from the animal house of Alkindy company for production of veterinary vaccines.Mice were housed in groups of (4) per plastic cage $(30 \times 10 \times 10) \mathrm{cm}$ in insulated room until the beginning of experiments. Standard rodent diet (Commercial Feed Pellets) and tap water were freely available.

\section{Plant Material:}

Dry Nigella sativa Linn.seeds were purchased from a local market in Baghdad, and were identified in the National herbarium at Abu Graib.

\section{Preparation of Seeds Suspension:}

Based on our previous study(15), to (10) gm of Nigella seeds, (100) $\mathrm{ml}$ of distilled water were added, mixed and ground by a blender, this was made for 5-6 intervals, 60 seconds each time, 60 second apart, at room temperature until complete grinding and mixing. A stock of a crude suspension a few minutes before each experiment was prepared by taking $10 \mathrm{ml}$ from stock solution contain 100mg, then a volume of $0.1 \mathrm{ml} / 10 \mathrm{gm} \mathrm{B.W}$ with a maximum of $0.3 \mathrm{ml}$.
Analgesic effect of Nigella seed suspension By Hot Plate Test:

Twenty four albino Swiss mice were used in this experiment and divided randomly into (4) groups (6 each)

Group (1): Treated orally with $1000 \mathrm{mg} / \mathrm{kg}$ B.W of watery suspension of Nigella sativa seeds only based on our previous study(6).

Group (2): Treated orally with $500 \mathrm{mg} / \mathrm{kg}$ B.W of Naproxen (7).

Group (3): Treated orally with both (500) $\mathrm{mg} / \mathrm{kg}$ B.W watery suspension of Nigella sativa and (250) $\mathrm{mg} / \mathrm{kg} \mathrm{B}$.W of Naproxen.

Group (4): Treated orally with distilled water only and served as control group.

Thirty minutes after administration, each animal in all groups was dropped gently on a plate maintained at $55 \pm 1 \mathrm{C}^{\circ}$. This constant temperature produces two behavioral components in mice that can be measured in terms of their reaction times, namely licking and flicking of the paw and jumping as described by ( 8 and 9).Measurement of reaction time were carried out also after 30, 60, 90, 120 minutes after administration of the test agents in order to gain more information about the analgesic activity of watery suspension of Nigella sativa seeds and its possible interaction with Naproxen.

\section{Results}

Oral administration of Nigella seed suspension showed significantly lower reaction time (analgesia) than treatment with Naproxen at 30 and 60 minutes. Reaction time of both treatments, however, approached each other with time with no significant difference at 90 and 120 minutes. Reaction times of both treatments were significantly higher than those of control values along the course time of treatment. This proved presence of analgesic effect of Nigella seeds suspension. Results indicate longer analgesic action of Nigella seed suspension than Naproxen, hence, the analgesic action of the later appeared to diminish with time. Combination of equal amounts of Nigella seeds suspension and Naproxen (half the originally used doses) resulted in prolongation of analgesic reaction time, which was rather longer than that shown by each agent when given alone referring an obvious synergistic effect (table, 1) and ( figure, 1). 
Table (1): Antinociceptive (reaction time) in mice treated orally with watery suspension of Nigella seeds, Naproxen or both together (hot plate test).

\begin{tabular}{|c|c|c|c|c|}
\hline \multirow{2}{*}{ Groups of mice } & \multicolumn{4}{|c|}{ Time after administration (minutes) } \\
\cline { 2 - 5 } & 30 & 60 & 90 & 120 \\
\hline Treated orally with watery & $\begin{array}{c}19.16 \pm 0.79 \\
\text { suspension of } N . s\end{array}$ & $\begin{array}{c}20.00 \pm 0.85 \\
\mathrm{~A}\end{array}$ & $\begin{array}{c}24.00 \pm 0.63 \\
\mathrm{~A}\end{array}$ & $\begin{array}{c}22.33 \pm 0.80 \\
\mathrm{~A}\end{array}$ \\
\hline Treated orally with Naproxen & $\begin{array}{c}26.00 \pm 0.52 \\
\mathrm{~B}\end{array}$ & $\begin{array}{c}24.50 \pm 0.76 \\
\mathrm{~B}\end{array}$ & $\begin{array}{c}23.50 \pm 0.76 \\
\mathrm{~A}\end{array}$ & $\begin{array}{c}21.83 \pm 0.90 \\
\mathrm{~A}\end{array}$ \\
\hline $\begin{array}{c}\text { Treated orally with watery } \\
\text { suspension of } N . s \text { then with } \\
\text { Naproxen }\end{array}$ & $\begin{array}{c}29.00 \pm 0.96 \\
\mathrm{C}\end{array}$ & $\begin{array}{c}29.33 \pm 0.95 \\
\mathrm{C}\end{array}$ & $\begin{array}{c}30.00 \pm 0.85 \\
\mathrm{~B}\end{array}$ & $\begin{array}{c}28.16 \pm 1.32 \\
\mathrm{~B}\end{array}$ \\
\hline $\begin{array}{c}\text { Control treated orally with } \\
\text { distilled water only }\end{array}$ & $\begin{array}{c}15.66 \pm 0.49 \\
\mathrm{D}\end{array}$ & $\begin{array}{c}14.66 \pm 0.49 \\
\mathrm{D}\end{array}$ & $\begin{array}{c}15.16 \pm 0.60 \\
\mathrm{C}\end{array}$ & $\begin{array}{c}14.50 \pm 0.42 \\
\mathrm{C}\end{array}$ \\
\hline
\end{tabular}

groups Figures represent mean \pm standard error.

Different large letters represent significant difference between groups vertically $(\mathrm{P}<0.05)$.

Similar large letters represent insignificant difference between vertically.

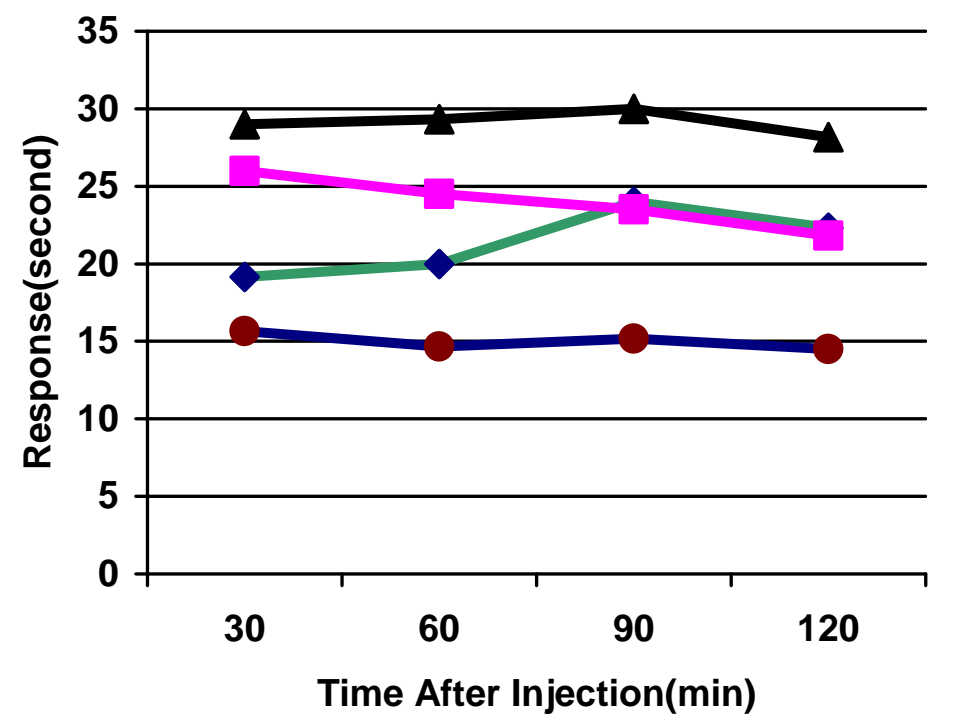

Nig. $=$ Nap. $\sim$ Nig.+Nap. - Control

Figure(1):Antinociceptive reaction in mice treated orally with watery suspention of N.seeds, Naproxen or both togather.(hot plate test)

\section{Discussion}

The present study demonstrated that the oral administration of watery suspension of Nigella sativa seeds produced a suppressive effect on nociceptive responses caused by thermal nociceptive stimuli in mice, as compared with animals in control group which were exposed to the same condition and with animals treated with naproxen.This antinociceptive effect of Nigella sativa is partly attributable to its component, thymoquinone which have been reported to produce antinociceptive effect through either indirect activation of supraspinal opioid receptors (10) or by inhibiting the cyclooxygenase and lipooxygenase pathways of arachidonic acid metabolism as reported by (11) who proposed that the inhibition of eicosanoid generation of the fixed oil of Nigella sativa is greater than is expected from its content of thymoquinone, so it could be concluded that there are substances other than thymoquinone responsible for analgesic activity such as p-cymene and pinene proved 
to have analgesic effects (3).Flavonoid, Rutine which present in Nigella sativa (12) and belongs to Qurectine group has an inhibitory effect on 5-lipooxygenase pathway (the main pathway for production of chemical mediators important in pain and inflammatory processes).(13).Some alkaloids, as reported in many situations in the literature (14), have important role in relieving pain. Chemical analysis of Nigella sativa seeds revealed the presence of alkaloids $(15,16,17)$, which may share other substance like flavonoids, and probably other substances, in relieving pain through elevation of pain threshold or diminishing inflammatory symptoms by inhibiting some chemical mediators important in initiating pain mechanism such as prostaglandins, leukotrienes and histamine discussed in a previous section of this study. Other mechanisms suggestive for analgesia as an activity of Nigella sativa seed suspension, are either depressing the ability of nociceptors to bind to chemical mediators or decreasing the conducting rate of nerve impulses along nerve fibers responsible for propagation and transport of impulses.The duration of analgesic action of orally administrated watery suspension of Nigella sativa seeds, varied with variable latency periods, it was significantly greater than the tolerance period of control animals 30 and 60 minutes after administration, but shorter than that of naproxen, Nigella and naproxen reaction periods approached each other as tested 90 minutes after treatment. The duration of reaction time due to Nigella sativa suspension, however, was greater than that of naproxen tested at 120 minutes after treatment. In addition, when Nigella sativa seeds suspension and naproxen were given simultaneously, the duration of their action, at all latency times, was significantly longer as compared to duration of reaction time due to Nigella suspension or naproxen each alone, this may suggest or support the possibility of different sites on which they act.

\section{References}

1. Lullman,H.Mohr,K.;Hein,L. and Bieg.er, D. (2005). Coloratlas of pharmacology. $3^{\text {rd }}$ ed ,Thieme. Stuttgart. New York.pp:6-7

2. Chakravarty, H.L. (1976). Plant wealth of Iraq - A dictionary of Economic Plants. Vol. 1. ministry of Agriculture and Agrarain Reform, Baghdad, Iraq.

3. Ahmed, Z.; Ghafoor, A. and Aslam, M. (2004). Nigella sativa - A potential commodity in crop diversification traditionally used in healthcare. Project on introduction of medicinal herbs and spices as crops, ministry of food, agriculture and livestock, Pakistan.

4. Atkinson,S.W.and Bihari,D.J.(1993).Preemptive analgesic .British Medical journal.36:285-287.

5. Randhawa, M.A. and A1-Ghamdi, M.S. (2002). A review of pharmaco therapeutic effects of Nigella sativa. Pakistan J. Med. Res. 41 (2):1-10.

6. Al-Shebani,W;H;S.(2005).Study of some pharmacological properties of watery suspension of Nigella sativa seeds.M.Sc. Thesis, college of Veterinary Medicine. Baghdad university, Iraq.

7. Hunskaar, S. and Hole, K.(1987). The formalin test in mice: dissociation between inflammatory and noninflammatory pain. Pain. 30 (1): 103-14.

8. Eddy, N. B. and Leimbach, D. (1953). J. pharmacol. Exp. Ther; 107: 385. cited by Bars, D. L.; Gozariu, M. and Samuel, W. (2001). Animal models of Nociception. Pharmacological Reviews. 53 (4): 597-652.

9. Abdon, A.P.; Cardoso, J.H.; Souza, A.N.; Morias, S.M. and Santos, C.F. (2002). Antinociceptive effect of the essential oil of Croton 
nepetaefolius on mice. Braz $\mathrm{J}$ med Biol Res. 35 (10): 1215-1219.

10. Abdel-Fattah, A.M.; Matsumoto, K. and Watanable, H. (2000). Antinociceptive effects of Nigella sativa oil and its major component, thymoquinone, in mice. Eur $\mathrm{J}$. Pharmacol.400 (1): 89-97.

11. Houghton, P.; Zarka, R.; Delas, H.B. and Hoult, R.S. (1995). Fixed oil of Nigella sativa and derived thymoquinone inhibit eicosanoid generation in Leukocytes and membrane lipid peroxidation. Planta Medica. 61: 33-36.

12. Al-Zubaidy, W. F. (2002). Isolation and identification of some flavonoids from Black seeds (Nigella sativa $\mathrm{L}$ ) and their anti-oxidant effects in vitro and on Blood Lipids profile in Rabbits. M. Sc. thesis. Department of physiology and pharmacology / College of Veterinary Medicine University of Baghdad

13. Ficarra, R.; Ficarra, P. and Slivana, T. (1995). Leaf extracts of some cordia species: Analgesic and anti- inflammatory activities as well as their chromatographic analysis. ILFarmaco. 50: 245-256

14. Alexander. F. (1973). An Introduction to Veterinary Pharmacology. 3rd ed. Churchill Livingstone. Edinburgh. London.

15. Atta-Ur-Rahman, A.; Malik, S.; Hasan, S.S.; Choudhary, M.N. and Clardy, J. (1995). Nigellidine, a new indazole alkaloid from the seeds of Nigella sativa. Tetrahedron Lett 36:1993-1996.

16. Atta-Ur-Rahman, A.; Malik, S. and Zaman, K. (1992). Nigellimine, a new isoquinoline alkaloid from the seeds of Nigella sativa. J. Nat Prod. 55:676-678.

17. Morikawa, T.X.; Ninomyia, K.; Matsuda, H. and Youshi, A. (2004). Nigellamines A3, A4, A5, and $\mathrm{C}$, new dolabellane type diterpene alkaloids, with lipid metabolism promoting activities from the Egyptian Medicinal food black cumin. Chem.. pharma. Bull. (Tokyo). 52(4):494-7.

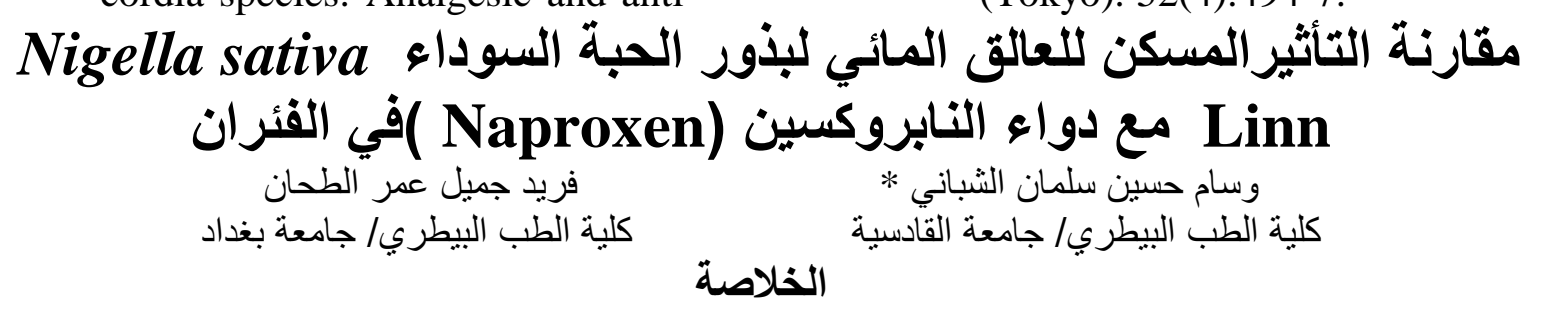

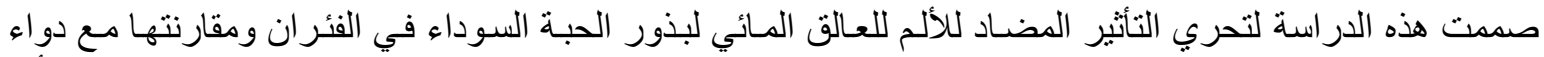

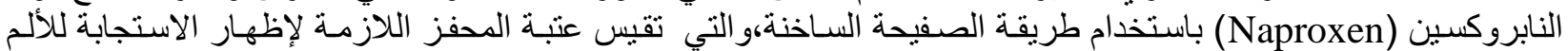

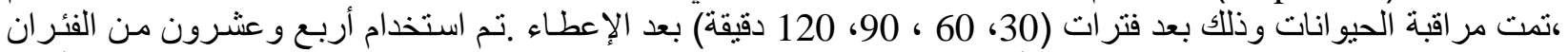

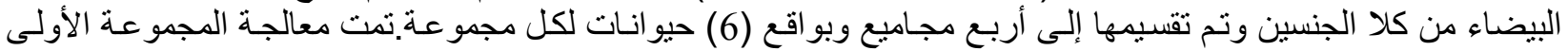

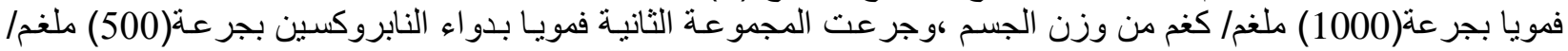

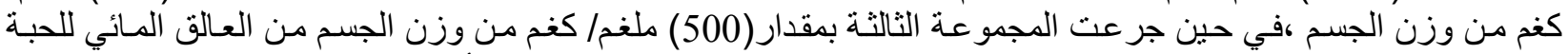

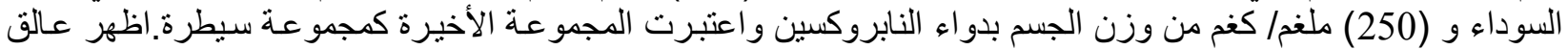

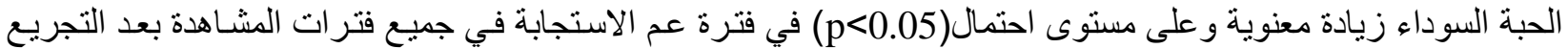

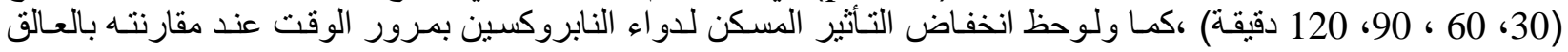

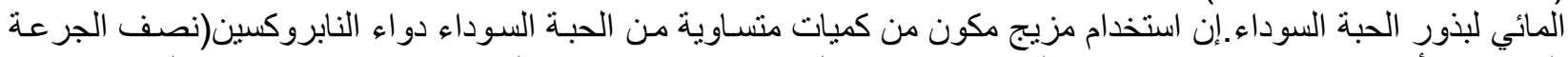

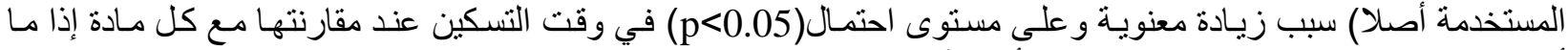
أعطيت بصورة منفردة مؤشر ا على وجود تأثنير تآزري و اضحى بين العالق المائي للحبة السوداء و دو اء النابروكسين . *|البحث مستل من أطروحة الماجستير للباحث الأول . 